Synthesis, Characterization and Antimicrobial Effect of $\mathrm{Cu}$ (II) and $\mathrm{Zn}$ (II)

Compounds Derived from 1,2,4-Triazoles

Síntese, Caracterização e Efeito antimicrobiano de Compostos de Cu(II) e

\title{
Zn(II) Derivados de 1,2,4-triazois
}

Article Info:

Article history: Received 2021-10-20 / Accepted 2022-01-01 / Available online 2022-01-01

doi: $10.18540 /$ jcecvl8iss 1pp13427-01-14e

Patricia Saraiva Vilas Boas de Almeida

ORCID: https://orcid.org/0000-0001-7205-2115

Departamento de Química, Universidade Federal de Viçosa, Brazil

E-mail: pvilasboas@yahoo.com.br

José Roberto da Silveira Maia

ORCID: https://orcid.org/0000-0001-5715-8763

Departamento de Química, Universidade Federal de Viçosa, Brazil

E-mail:jrsmaia@ufv.br

Mariana Caliman Falqueto

ORCID: https://orcid.org/0000-0002-3777-6537

Departamento de Química, Universidade Federal de Viçosa, Brazil

E-mail: marianacaliman40@ufv.br

Leandro Licursi de Oliveira

ORCID: https://orcid.org/0000-0003-4353-7011

Departamento de Biologia Geral, Universidade Federal de Viçosa, Brazil

E-mail: leandro.licursi@ufv.br

\section{Resumo}

Compostos de $\mathrm{Cu}(\mathrm{II})$ e $\mathrm{Zn}(\mathrm{II})$ com 3-R-1H-1,2,4-triazol-5-amina $\{\mathrm{R}=$ metila ( $m$ ta), fenila (pta) $\}$ foram preparados e caracterizados por espectroscopia no infravermelho (IV), RMN multinuclear $\left({ }^{1} \mathrm{H},{ }^{13} \mathrm{C}\right)$, espectroscopia eletrônica (UV-VIS), análise termogravimétrica (TGA), calorimetria de digitalização diferencial (DSC), microanálise e ponto de fusão. Materiais diméricos, monoméricos e poliméricos foram sintetizados neste trabalho. Os derivados $\mathrm{Zn}$ (II)-1,2,4-triazol têm o íon metálico no centro de dois arranjos geométricos, sendo um tetraedro para os complexos-7 e 9, e um octaedro para o complexo-8. O único material polimérico, complexo-7, foi caracterizado pelos dados analíticos do DSC. A reação de decomposição do complexo-8 em clorofórmio produziu o complexo9, um derivado de aminoguanidina, e o composto Zn(II)-benzoato. O IV e UV-VIS dos derivados $\mathrm{Cu}$ (II)-mta revelaram dois padrões geométricos possíveis para o íon metálico; uma geometria trigonal bipiramidal distorcida para os compostos 10 e 11 em solução, e no estado sólido, a mesma geometria para o complexo-10, porém para o complexo-11, os dados de IV sugerem uma geometria octaédrica distorcida. O ensaio biológico dos compostos 1,2,4 triazol e seus derivados metálicos contra bactérias Gram-positivas e Gram-negativas mostrou os compostos de $\mathrm{Zn}$ (II) como os únicos materiais ativos com valores de MIC dentro da faixa de 133,5 $\mu \mathrm{M}(83,3 \mu \mathrm{g} / \mathrm{mL})$ a 360,7 $\mu \mathrm{M}(166,6$ $\mu \mathrm{g} / \mathrm{mL})$.

Palavras-chave: $\mathrm{Cu}(\mathrm{II})$. $\mathrm{Zn}(\mathrm{II})$. Efeito Antimicrobiano. Compostos 1,2,4-triazois. Metais de Transição.

\footnotetext{
Abstract

Compounds of $\mathrm{Cu}(\mathrm{II})$ and $\mathrm{Zn}(\mathrm{II})$ with 3-R-1H-1,2,4-triazole-5-amine $\{\mathrm{R}=$ methyl ( $m+a)$, phenyl $(p t a)\}$ were prepared and characterized by infrared spectroscopy (IR), multinuclear NMR $\left({ }^{1} \mathrm{H},{ }^{13} \mathrm{C}\right)$, electronic spectroscopy (UV-VIS), thermogravimetric analysis (TGA), differential scanning calorimetry (DSC), microanalyses and melting point. Dimeric, monomeric, and polymeric materials
} 
were synthesized in this work. The $\mathrm{Zn}(\mathrm{II})-1,2,4$-triazole derivatives have the metal ion at the center of two geometric arrangements, being a tetrahedron for the complex-7 and 9, and an octahedron for the complex-8. The only polymeric material, complex-7, was characterized by the DSC analytical data. The Decomposition reaction of complex-8 in chloroform produced the complex-9, a aminoguanidine derivative, and the $\mathrm{Zn}$ (II)-benzoate compound. The IR and UV-VIS of Cu(II)-mta derivatives revealed two possible geometric patterns for the metallic ion; a distorted bipyramidal trigonal geometry for compounds $\mathbf{1 0}$ and $\mathbf{1 1}$ in solution, and in the solid state, the same geometry for complex-10, but for complex-11, the IR data suggest a distorted octahedral geometry. The biological assay of the 1,2,4-triazole compounds and their metal derivatives against Gram-positive and Gram-negative bacteria shown the compounds of $\mathrm{Zn}$ (II) as the only active materials with values of MIC within the range of $133.5 \mu \mathrm{M}(83.3 \mu \mathrm{g} / \mathrm{mL})$ to $360.7 \mu \mathrm{M}(166.6 \mu \mathrm{g} / \mathrm{mL})$.

Keywords: $\mathrm{Cu}(\mathrm{II})$. Zn(II). Antimicrobial effect. 1,2,4-triazole compounds. Transition metals.

\section{Introduction}

The triazole compounds are acknowledged by their pharmacologic activity as antiviral, antifungal, bactericidal and antidepressant drugs, as well as in asthma treatment (Deng, Song, Zheng, \& Quan, 2014; Naito et al., 1996). Several triazole drugs such as Fluconazole, Itraconazole and Ravuconazole have antifungal properties based on the inhibition of ergosterol, a steroid compound found in fungi cell membranes (Johnson, Szekely, \& Warnock, 1999; Roberts, Schock, Marino, \& Andriole, 2000). Ribavirin is also a triazole drug used by means of aerosols for the treatment of viral diseases associated to the lower respiratory tract (Graci \& Cameron, 2006).

The chemical elements copper and zinc are known by have an important participation on the metabolism of living organisms. The chemistry of these elements is extensive and the use of their compounds for the treatment of diseases have shown significant results. For instance, complexes of $\mathrm{Cu}$ (II) and $\mathrm{Zn}$ (II)-triazole, derivatives of Schiff bases, have been reported to be active in vitro against strains of Escherichia coli, Aspergillus niger, and Aspergillus flavus. Coordination compounds of these metals with other ligand type such as the antibiotic levofloxacin and the $\mathrm{Cu}(\mathrm{II})$ ion are reported as inhibitors of the growing of microorganisms by the formation of strong chemical bonds to their DNA, preventing their replication, and consequently, the death of the microbes. Antitumoral and bactericidal activity also are documented for several other compounds of $\mathrm{Cu}$ (II) (Galani et al., 2014; Ma et al., 2015).

Following our interest on bacterial activity of metal coordination compounds, novel complexes of $\mathrm{Zn}(\mathrm{II})$ and $\mathrm{Cu}(\mathrm{II})$ involving the ligands 3-R- $1 \mathrm{H}-1,2,4$-triazole-5-amine $\{\mathrm{R}=$ phenyl (pta), methyl (mta) \} were prepared and tested against strains of Staphylococcus aureus, Bacillus subtilis, Escherichia coli and Salmonella typhimurium.

\section{Materials and methods}

Solvents and reactants, purchased from Sigma-Aldrich Company, have been used without prior purification. A Perkin Elmer $200 \mathrm{CHNS}$ Elemental Analyzer equipment provided the microanalysis data of the compounds. A Perkin Elmer FT-IR 1000 equipment recorded the infrared spectra of the compounds in Nujol between CsI windows. The Varian Mercury $300 \mathrm{MHz}$ equipment has collected the multinuclear NMR data $\left({ }^{1} \mathrm{H}\right.$ and $\left.{ }^{13} \mathrm{C}\right)$ in $\mathrm{CDCl}_{3}, \mathrm{CD}_{3} \mathrm{OD}$ and DMSO- $\mathrm{d}_{6}$, using TMS as reference. A Shimadzu equipment, model DTG-60 provided the thermal gravimetric (TGA) and the differential scanning calorimetry (DSC) analysis. The heating rate was $10{ }^{\circ} \mathrm{C} / \mathrm{min}$ under nitrogen flow $(50 \mathrm{~mL} / \mathrm{min})$ within the temperature range of 30 to $1100{ }^{\circ} \mathrm{C}$ (TGA) and 30 to $600{ }^{\circ} \mathrm{C}$ (DSC). Crucibles of aluminum and platinum were used throughout the DSC and TGA thermal analysis. A Mettler equipment model MQAPF-301 recorded the melting point of the compounds. The broth microdilution method was used for the biological assay in BioRad microplates, model 3550-UV (USA). The minimum inhibitory concentration (MIC) was collected by a 
spectrophotometer Eliza $(600 \mathrm{~nm})$.

\subsection{Synthesis Of The 1,2,4-Triazoles}

The compounds $m t a$ and pta were synthesized by the condensation reaction between aminoguanidine bicarbonate $(a m g u)$ with acetic acid or benzoic acid (Boechat, Pinheiro, SantosFilho, \& Silva, 2011). These compounds were filtered off in air, washed with hexane and kept in desiccators prior to use in complexation reactions with $\mathrm{Zn}$ (II) and $\mathrm{Cu}(\mathrm{II})$ chlorides. The molecular structures of the 1,2,4-triazoles and their precursor are shown by Figure 1.

3-Methyl-1H-1,2,4-triazole-5-amine (mta): IR (Nujol, CsI): 3314, $3449 v(\mathrm{~N}-\mathrm{H}), 3186$ $v_{\text {as }}\left(\mathrm{NH}_{2}\right) ; 3039 v_{\mathrm{s}}\left(\mathrm{NH}_{2}\right) ; 1629,1666 v(\mathrm{C}=\mathrm{N}) ; 2881 v\left(\mathrm{CH}_{3}\right)$.

3-Phenyl-1H-1,2,4-triazole-5-amine (pta): IR (Nujol, CsI): $3407 v(\mathrm{~N}-\mathrm{H}) ; 3361,3274 v\left(\mathrm{NH}_{2}\right)$; 1682, $1668 v(\mathrm{C}=\mathrm{N}) ; 841 \delta(\mathrm{C}-\mathrm{H}) .{ }^{1} \mathrm{H}$ NMR $\left(\mathrm{CD}_{3} \mathrm{OD}, 300 \mathrm{MHz}, \delta\right): 4.93\left(\mathrm{~s}, \mathrm{NH}_{2}\right) ; 7.93(\mathrm{~d}, \mathrm{Ph}), 7.32$ - $7.44(\mathrm{~m}, \mathrm{Ph}),{ }^{13} \mathrm{C} \mathrm{NMR}\left(\mathrm{CD}_{3} \mathrm{OD}, 75 \mathrm{MHz}, \delta\right): 174.5\left(\mathbf{C}-\mathrm{NH}_{2}\right), 159.8(\mathbf{C}-\mathrm{Ph}), 137.6,130.2,129.0$, $127.6(\mathrm{Ph})$.

Aminoguanidine bicarbonate: IR (Nujol / CsI): $3350 v(\mathrm{~N}-\mathrm{H}), 3251,3136 v\left(\mathrm{NH}_{2}\right) ; 1686,1632$ $v(\mathrm{C}=\mathrm{N}) ; 1355 v\left(\mathrm{HCO}_{3}\right)$.<smiles>Cc1n[nH]c(N)n1</smiles>

3-methyl-1H-1,2,4-triazole-5-amine ( $m$ ta)<smiles>Nc1nc(-c2ccccc2)n[nH]1</smiles>

3-phenyl-1H-1,2,4-triazole-5-amine (pta)<smiles>N=C(N)NNCC(=O)O</smiles>

Aminoguanidine bicarbonate

Figure 1 - Molecular structures of the 1,2,4-triazoles and the aminoguanidine precursor.

\subsection{Synthesis Of The 1,2,4-Triazole Metal Derivatives}

The metal complexes were soluble in usual solvents such as acetonitrile, methanol, ethanol, chloroform and DMSO, except the compound 7. These complexes of $\mathrm{Zn}$ (II) and $\mathrm{Cu}$ (II) were synthesized according to the general procedure:

Experimental procedure for the compounds of $\mathrm{Zn}(\mathrm{II})$ : To a round-bottom flask of $100 \mathrm{~mL}$, $1.80 \mathrm{mmol}$ of $\mathrm{Zn}$ (II) chloride was mixed with $1.83 \mathrm{mmol}$ of the corresponding triazole in methanol ( $m t a, 25 \mathrm{~mL}$ ) or ethanol (pta, $30 \mathrm{~mL})$. The mixture was maintained under magnetic stirring at room temperature for $3 \mathrm{~h}$. Subsequently, the solvent was removed under reduced pressure until a solid appear in the flask, which was filtered off in air, washed with diethyl ether, and stored in glass desiccator. The attempt of purifying compound $\mathbf{8}$ in chloroform led to the formation of a white solid. After filtration under reduced pressure, the solid was identified by infrared spectroscopy as being the zinc(II) benzoate (Egashira, Sakai, Takayama, Sakurai, \& Yoshida, 2003). From the filtrate, 
another solid, complex-9, was obtained after removing half of the solvent through a rotary evaporator. After filtering, the solid was washed with hexane and left to dry in a desiccator.

$\left[\mathrm{Zn}_{2}(m t a)_{2} \mathrm{Cl}_{2}\right] \cdot \mathrm{H}_{2} \mathrm{O}(7)$ : Colour: white. Yield: $0.303 \mathrm{~g}(50 \%) . \mathrm{Mp}\left({ }^{\circ} \mathrm{C}\right),>200 \mathrm{~d}$. Elemental analyses required for $\mathrm{C}_{6} \mathrm{H}_{14} \mathrm{~N}_{8} \mathrm{OZn}_{2} \mathrm{Cl}_{2}$ : C, 17.33; H, 3.39; N, 26.94. Found: $\mathrm{C}, 17.15 ; \mathrm{H}, 2.27 ; \mathrm{N}$, 25.47; IR (Nujol, CsI, $\left.v_{\text {máx }} / \mathrm{cm}^{-1}\right)$ : 3443; $3414 v\left(\mathrm{H}_{2} \mathrm{O}\right) ; 3337 v(\mathrm{NH}) ; 1646 v(\mathrm{C}=\mathrm{N}) ; 389,366 v(\mathrm{Zn}-$ $\mathrm{N}) ; 317,302 v(\mathrm{Zn}-\mathrm{Cl})$.

$\left[\mathrm{Zn}_{2}(p t a)_{2} \underline{\mathrm{Cl}}_{4}\right] \cdot 3 \mathrm{H}_{2} \mathrm{O}(\mathbf{8})$ : Colour: beije. Yield: $0.539 \mathrm{~g}(78 \%) . \mathrm{Mp}\left({ }^{\circ} \mathrm{C}\right), 209 \mathrm{~d}$. Elemental analysis required for $\mathrm{C}_{16} \mathrm{H}_{22} \mathrm{~N}_{8} \mathrm{O}_{3} \mathrm{Zn}_{2} \mathrm{Cl}_{4}: \mathrm{C}, 29.70 ; \mathrm{H}, 3.43 ; \mathrm{N}, 17.32$. Found: $\mathrm{C}, 30.28 ; \mathrm{H}, 3.06 ; \mathrm{N}$, 14.03; IR (Nujol, CsI, $\left.v_{\text {máx }} / \mathrm{cm}^{-1}\right)$ : $3433 v\left(\mathrm{H}_{2} \mathrm{O}\right) ; 3350 v(\mathrm{NH}) ; 3325,3308 v\left(\mathrm{NH}_{2}\right) ; 1659,1639$ $v(\mathrm{C}=\mathrm{N}) ; 528,495 v(\mathrm{Zn}-\mathrm{O}) ; 465,242 v(\mathrm{Zn}-\mathrm{N}) ; 341,323,292,268 v(\mathrm{Zn}-\mathrm{Cl}) ;{ }^{1} \mathrm{H}$ NMR $\left(\mathrm{CD}_{3} \mathrm{OD}, 300\right.$ $\mathrm{MHz}, \delta): 4.91\left(\mathrm{~s}, \mathrm{NH}_{2}\right) ; 8.02(\mathrm{~d}, \mathrm{Ph}) ; 7.36-7.47(\mathrm{~m}, \mathrm{Ph}) .{ }^{13} \mathrm{C} \mathrm{NMR}\left(\mathrm{CD}_{3} \mathrm{OD}, 75 \mathrm{MHz}, \delta\right): 173.7$ $\left(\mathbf{C}-\mathrm{NH}_{2}\right), 159.5(\mathbf{C}-\mathrm{Ph}), 134.2,131.1,129.4,127.5(\mathrm{Ph})$.

$\left[\mathrm{Zn}_{2}(\text { amgu })_{2} \underline{\mathrm{Cl}}_{2}\right] \cdot \mathrm{CHCl}_{3}(9)$ : Colour: beije. Yield: $0.269 \mathrm{~g}(50 \%) . \mathrm{Mp}\left({ }^{\circ} \mathrm{C}\right), 162 \mathrm{~d}$. Elemental analyses required for $\mathrm{C}_{3} \mathrm{H}_{13} \mathrm{~N}_{8} \mathrm{Zn}_{2} \mathrm{Cl}_{5}: \mathrm{C}, 7.68 ; \mathrm{H}, 2.79 ; \mathrm{N}, 23.8$. Found: $\mathrm{C}, 7.71 ; \mathrm{H}, 2.37 ; \mathrm{N}, 23.99$; IR (Nujol, CsI, $\left.v_{\text {máx }} / \mathrm{cm}^{-1}\right)$ : $3324 v(\mathrm{NH}), 3221,3196 v\left(\mathrm{NH}_{2}\right) ; 1662,1639 v(\mathrm{C}=\mathrm{N}) ; 508,529 v(\mathrm{Zn}-$ $\mathrm{N}) ; 303,292 v(\mathrm{Zn}-\mathrm{Cl}) ;{ }^{1} \mathrm{H}$ NMR (DMSO-d $\left.6,300 \mathrm{MHz}, \delta\right): 4.65\left(\mathrm{~s}, \mathrm{NH}_{2}\right) ; 6.74$ (s, $\mathrm{NH}_{2}$, broad); 7.24 (s, $\mathrm{NH}_{2}$, broad); 8.56 (s, NH). ${ }^{13} \mathrm{C}$ NMR (DMSO-d 6 , $\left.75 \mathrm{MHz}, \delta\right): 159.3,155.8\left(\mathbf{C}-\mathrm{NH}_{2}\right)$.

[Zn(PhCOO) 2 ]: IR (Nujol, CsI, v máx $\left./ \mathrm{cm}^{-1}\right): 1689 v(\mathrm{CO}) ; 1454 v_{\text {as }}(\mathrm{COO}), 1402 v_{\mathrm{s}}(\mathrm{COO}) ; 709$ $v(\mathrm{CH}, \mathrm{Ph}) ; 497 v(\mathrm{Zn}-\mathrm{O}) .{ }^{1} \mathrm{H} \mathrm{NMR}\left(\mathrm{CDCl}_{3}, 300 \mathrm{MHz}, \delta\right): 8.13(\mathrm{~d}, \mathrm{Ph}), 7.63-7.45(\mathrm{~m}, \mathrm{Ph}) .{ }^{13} \mathrm{C} \mathrm{NMR}$ $\left(\mathrm{CDCl}_{3}, 75 \mathrm{MHz}, \delta\right): 172.4(\mathrm{C}=\mathrm{O}), 133.6,130.2,129.6,128.4(\mathrm{Ph})$.

Experimental procedure for the compounds of $\mathrm{Cu}(\mathrm{II})$ : To a round-bottom flask of $100 \mathrm{~mL}$, $1.50 \mathrm{mmol}$ of $\mathrm{Cu}$ (II) chloride was added together with $3.05 \mathrm{mmol}$ of $\mathrm{mta}$ in methanol $(30 \mathrm{~mL})$. The mixture was kept under magnetic stirring at room temperature for $2 \mathrm{~h}$. A moss green solid was obtained which, after filtering off in air, was washed with diethyl ether and stored in glass desiccator. From the filtrate, a dark green solid was separated after removing the solvent under reduced pressure till dryness.

$\left[\mathrm{Cu}_{2}(m t a){ }_{2} \underline{C l}_{4}\right] \cdot \mathrm{H}_{2} \mathrm{O}(\mathbf{1 0})$ : Colour: dark green. Yield: $0.280 \mathrm{~g}(50 \%)$. Mp $\left({ }^{\circ} \mathrm{C}\right), 188 \mathrm{~d}$. Elemental analyses required for $\mathrm{C}_{6} \mathrm{H}_{12} \mathrm{~N}_{8} \mathrm{Cu}_{2} \mathrm{Cl}_{4}: \mathrm{C}, 14.92 ; \mathrm{H}, 2.92 ; \mathrm{N}, 23.19$. Found: $\mathrm{C}, 14.05 ; \mathrm{H}$, 2.71; N, 22.17; IR (Nujol, CsI, v máx / $\left.\mathrm{cm}^{-1}\right)$ : $3435 v\left(\mathrm{H}_{2} \mathrm{O}\right) ; 3284,3175 v\left(\mathrm{NH}_{2}, \mathrm{NH}\right) ; 1636 v(\mathrm{C}=\mathrm{N})$; $398 v(\mathrm{Cu}-\mathrm{N})$; 278, 256, $246 \mathrm{v}(\mathrm{Cu}-\mathrm{Cl})$. UV-VIS $\left(\mathrm{CH}_{3} \mathrm{OH}, 10^{-3} \mathrm{~mol} / \mathrm{L}\right): 719 \mathrm{~nm}\left(13,908 \mathrm{~cm}^{-1}, \varepsilon=\right.$ $76.7 \mathrm{~L} / \mathrm{mol} . \mathrm{cm})$.

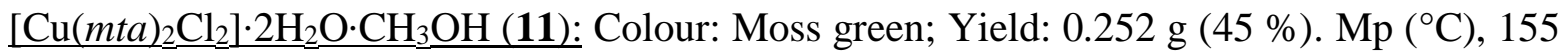
d. Elemental analyses required for $\mathrm{C}_{7} \mathrm{H}_{19} \mathrm{~N}_{8} \mathrm{O}_{3} \mathrm{CuCl}_{2}$ : C, 21.14; H, 4.82; N, 28.17. Found: C, 20.79; H, 3.56; N, 28.41. IR (Nujol / CsI, v máx $\left./ \mathrm{cm}^{-1}\right)$ : 3529, $3438 v\left(\mathrm{H}_{2} \mathrm{O}\right) ; 3344,3301 v\left(\mathrm{NH}_{2}, \mathrm{NH}\right) ; 1635$ $v(\mathrm{C}=\mathrm{N}) ; 504 v\left(\mathrm{H}_{2} \mathrm{O}\right) ; 359 v(\mathrm{Cu}-\mathrm{N}) ; 276 v(\mathrm{Cu}-\mathrm{Cl})$. UV-VIS $\left(\mathrm{CH}_{3} \mathrm{OH}, 10^{-2} \mathrm{~mol} / \mathrm{L}\right): 723 \mathrm{~nm}(13,831$ $\left.\mathrm{cm}^{-1}, \varepsilon=7.0 \mathrm{~L} / \mathrm{mol} . \mathrm{cm}\right)$.

\subsection{Minimum Inhibitory Concentration (MIC)}

The Minimum Inhibitory Concentration used the broth microdilution technique through microplates of 96 wells (Bianucci et al., 1991; NCCLS, 2002, 2003; Zacchino \& Gupta, 2007). The standard solution $(1000 \mu \mathrm{g} / \mathrm{mL})$ was prepared by dissolving $1.0 \mathrm{mg}$ of the substance to be tested in a mixture of DMSO $(250 \mu \mathrm{L})$ and sterile water $(750 \mu \mathrm{L})$. Aliquots for the biological assay screening were prepared diluting the standard solution to the concentration range of 1973 to $0.5 \mu \mathrm{M}$ (333 to $0.2 \mu \mathrm{g} / \mathrm{mL}$ ). Each of the bacteria strain were grown in $3.0 \mathrm{~mL}$ of Luria Bertani (LB) at 
$37{ }^{\circ} \mathrm{C}$ until an optical density (OD) between 0.08 and 0.10 which corresponds to the range of 1.0 to $2.0 \times 10^{8}$ colony-forming unit $(\mathrm{CFU} / \mathrm{mL})$. Afterwards, $100 \mu \mathrm{L}\left(5.0 \times 10^{4} \mathrm{CFU}\right)$ of LB from each bacterial strain added to $50 \mu \mathrm{L}$ of each substance of being tested. The resultant mixture was then transferred to microplates, incubated throughout $24 \mathrm{~h}$ and scanned using a spectrometer ELISA at $600 \mathrm{~nm}$. The experiment was finished in duplicate considering the standard deviation. The strains of bacteria used in the biological assay of the $\mathrm{Zn}(\mathrm{II})$ - and $\mathrm{Cu}(\mathrm{II})-1,2$,4-triazole compounds were Staphylococcus aureus (ATCC33591), Bacillus subtilis (ATCC 23858), Escherichia coli (ATCC 29214) and Salmonella typhimurium (ATCC 14028). The DMSO was the negative control, and both Amoxicillin and Norfloxacin the positive control.

\section{Results and discussion}

\subsection{Infrared Spectroscopy}

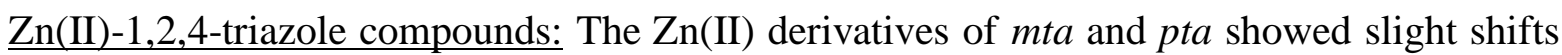
towards low frequency correlated to the vibrational stretching $\mathrm{v}(\mathrm{NH})$ and $\mathrm{v}(\mathrm{C}=\mathrm{N})$ of the amine and imine groups, indicating the formation of a new metal-ligand bond. The vibrations associated to the primary amines $\left(\mathrm{NH}_{2}\right)$ arisen in the range of 3200 to $3400 \mathrm{~cm}^{-1}$ as double bands of medium intensity, and the secondary amines $(\mathrm{NH})$ as single weak bands in the region of $3330 \mathrm{~cm}^{-1}$. Similar assignments to that found in the compound of Cadmium(II)-3,4-diamino-1,2,4-triazole (Jin, $\mathrm{Xu}, \mathrm{Yin}, \mathrm{He}, \&$ Zhang, 2015; Silverstain, Bassler, \& Morril, 1991).

Complex-7 showed a unique absorption at $3337 \mathrm{~cm}^{-1}$, characteristic of a secondary amine. The typical double band for the primary amine group of the $m t a$ compound is absent in the infrared spectrum of the complex-7. Based on this spectroscopic evidence, the chemical bond between the amine group and the metal ion favors the loss of hydrogen chloride, which corroborates with the $\mathrm{CNH}$ analyses of complex-7. The thermogravimetric analysis (TGA) and differential scanning calorimetry (DSC) complements the infrared data, providing better insight regarding the polymeric properties of complex-7.

Two vibrations for the complex-8, relative to the primary amine group, had a slight shift towards low frequency. Because of the hydrogen bonding involving primary and secondary amine groups, a small change in the infrared spectra becomes a challenging task for defining the formation of metal-nitrogen bonds by coordination (Nakamoto, 1997). Nevertheless, both complexes, $\mathbf{7}$ and $\mathbf{8}$, showed vibrational shifts towards low frequency for the imine group, confirming the metal is bonded to the ring of the triazole by a nitrogen atom.

At the low frequency, two absorptions related to the vibrational stretching of the metalnitrogen bond, in the region of $377 \mathrm{~cm}^{-1}$ for complex-7, and two others in the region of $353 \mathrm{~cm}^{-1}$ for complex-8 (at 465 and $242 \mathrm{~cm}^{-1}$ ) showed up in the spectrum of these compounds. The band at 465 $\mathrm{cm}^{-1}$ correlates the group amine bonded to metallic ions (Mohamed, Ahmami, \& Ali, 2016; Nakamoto, 1997). These two absorptions indicate that the mta and pta bond to the metal by a bidentate coordination mode with the nitrogen atoms of the triazole compounds in cis configuration. Complex-8 also showed an infrared stretching assigned to metal-oxygen bonds in the region of 511 $\mathrm{cm}^{-1}$ that correlates to coordinated water molecules (Arjmand, Sayeed, \& Muddassir, 2011; Mohamed et al., 2016; Nakamoto, 1997). Two bands in complex-7, which have proximate energy and intensity, correlate to the bridging vibrational mode for the chlorine atoms relative to the metal (Berlini et al., 2009; Devi et al., 2014; Indoria et al., 2015; Nakamoto, 1997). In complex-8, four absorptions of low to medium intensity, in the range 268 to $341 \mathrm{~cm}^{-1}$, are also associated to bridge and terminal vibrational modes for the metal-chlorine bonds (Devi et al., 2014; Nakamoto, 1997). Based on this data, dimeric compounds having a structural feature of a distorted tetrahedron and an octahedral geometry are conceivable for the complex-7 and $\mathbf{8}$ in solid state, as shown by Figure 2. 


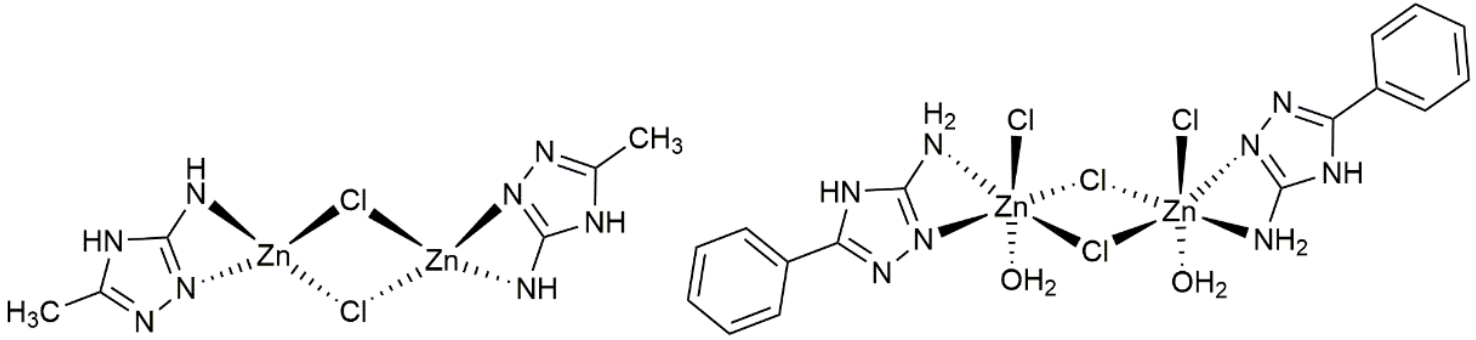<smiles>OC(Cl)(Cl)C(Cl)(Cl)Nc1nnc(-c2ccccc2)[nH]1</smiles>

$8 b$

Figure 2 - Proposed dimeric arrangements for the $\mathrm{Zn}(\mathrm{II})$-mta (7), and $\mathrm{Zn}$ (II)-pta (8) compounds.

A new $\mathrm{Zn}(\mathrm{II})$ derivative of aminoguanidine (amgu), complex-9, was obtained by the decomposition reaction of complex-8 in chloroform. The former compound showed distinct infrared spectrum compared to the latter, presenting shifts relative to the primary amine, $v\left(\mathrm{NH}_{2}\right)$, at 3221 and 3196 , and secondary amine, $v(\mathrm{NH})$, in $3324 \mathrm{~cm}^{-1}$ correlated to the coordinated aminoguanidine. Although it is not possible to compare these shifts with the spectrum of the free ligand, the two infrared bands of the imine group from complex-9 compares with those of the free aminoguanidine bicarbonate compound. The two vibrational stretching of the imine group in this complex shifted slightly reinforcing formation of bidentate coordination mode for this ligand.

The metal-chlorine stretching at 303 and $292 \mathrm{~cm}^{-1}$ suggest bridging coordination mode for the chlorine atoms in this complex (Devi et al., 2014; Indoria et al., 2015). In consequence of that, a dimeric tetrahedral structure in solid state for complex-9 is possible as shown by Figure 3. The coordination of aminoguanidine hydrochloride is known and reported in compounds of $\mathrm{Pd}(\mathrm{II})$ and $\mathrm{Pt}(\mathrm{II})$. The X-ray structural analysis for these compounds of square planar geometry showed this ligand coordinated in bidentate and monodentate modes (J. et al., 2007).

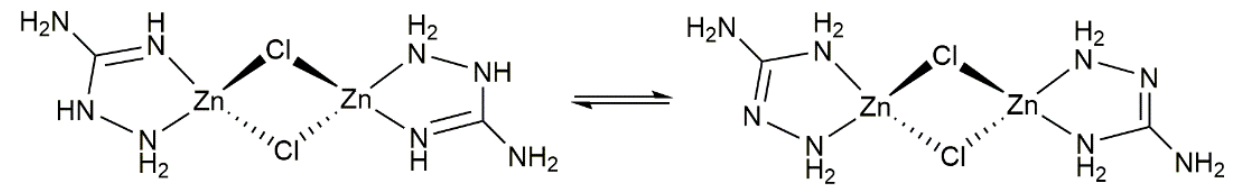

Figure 3 - Dimeric equilibrium in the solid state for complex-9. 
$\mathrm{Cu}(\mathrm{II})-1,2,4$-triazole compounds: The $\mathrm{Cu}$ (II) derivatives of $m t a$ showed stretching vibrations of the imine group in the region of $1635 \mathrm{~cm}^{-1}$, which is in lower frequency compared to the free ligand. This effect is evidence that the coordination of the metal occurred by the triazole ring, analogous to the $\mathrm{Zn}$ (II) complexes. The stretching vibrations of the amine group shifted slightly towards low frequency in complex-11 which may be correlated to a weak metal-nitrogen bond or due to formation of hydrogen bonding through the coordinated amine groups (Nakamoto, 1997).

However, at the low frequency, complex-10 and $\mathbf{1 1}$ showed vibrations correlated to metalnitrogen bond at $398 \mathrm{~cm}^{-1}$ and $359 \mathrm{~cm}^{-1}$ respectively. The unique band associated to metal-chlorine bond in complex-11 and the three ones in complex-10 indicate terminal and bridging coordination modes for the chlorine atoms (Devi et al., 2014; Nakamoto, 1997). Other broad band at $504 \mathrm{~cm}^{-1}$ for complex-11 was associated to vibrations of lattice water molecules (Nakamoto, 1997). Similar coordination modes for the chlorine atoms can be seen on the crystal structure of the dimeric compound Cd(II)-3,4-diamino-1,2,4-triazole (Jin et al., 2015). The infrared data of complex-10 and 11 suggest that the $\mathrm{Cu}$ (II) ion is probably at the center of a distorted trigonal bipyramidal geometry for the former, and at the center of an octahedron for the latter. Proposed structures for the $\mathrm{Cu}$ (II)mta complexes are shown by Figure 4. A summary of the major infrared data for the compounds prepared in this work are shown in Table 1.

Table 1 - Infrared data of the 1,2,4-triazole compounds and its metal derivatives.

\begin{tabular}{lllllll}
\hline Compound & $v(\mathrm{~N}-\mathrm{H})$ & $v\left(\mathrm{NH}_{2}\right)$ & $v(\mathrm{C}=\mathrm{N})$ & $v(\mathrm{M}-\mathrm{O})$ & $v(\mathrm{M}-\mathrm{N})$ & $v(\mathrm{M}-\mathrm{Cl})$ \\
\hline \multirow{2}{*}{ Amgu } & 3350 & 3251,3136 & 1686,1632 & & & \\
$m t a$ & 3314,3449 & 3186,3039 & 1629,1666 & & & \\
$p t a$ & 3407 & 3361,3274 & 1682,1668 & & & \\
$\mathbf{7}$ & 3337 & & 1646 & & 389,366 & 317,302 \\
$\mathbf{8}$ & 3350 & 3325,3308 & 1659,1639 & 528,495 & 465,242 & 341,323 \\
$\mathbf{9}$ & 3324 & 3221,3196 & 1662,1639 & & 508,529 & 303,292 \\
$\mathbf{1 0}$ & 3284 & 3175 & 1636 & & 398 & 278,256 \\
$\mathbf{1 1}$ & 3334 & 3301 & 1635 & & 359 & 246 \\
& & & & & & \\
\hline
\end{tabular}

Note: $\mathrm{cm}^{-1} ;\left[\mathrm{Zn}_{2}(m t a)_{2} \mathrm{Cl}_{2}\right] \cdot \mathrm{H}_{2} \mathrm{O}(\mathbf{7}) ;\left[\mathrm{Zn}_{2}(p t a)_{2} \mathrm{Cl}_{4}\right] \cdot 3 \mathrm{H}_{2} \mathrm{O}(\mathbf{8}) ;\left[\mathrm{Zn}_{2}(a m g u)_{2} \mathrm{Cl}_{2}\right] \cdot \mathrm{CHCl}_{3}(\mathbf{9}) ;\left[\mathrm{Cu}_{2}(m t a)_{2} \mathrm{Cl}_{4}\right] \cdot \mathrm{H}_{2} \mathrm{O}(\mathbf{1 0})$; $\left[\mathrm{Cu}(m t a)_{2} \mathrm{Cl}_{2}\right] \cdot 2 \mathrm{H}_{2} \mathrm{O} \cdot \mathrm{CH}_{3} \mathrm{OH}(\mathbf{1 1}) ;$ amgu - aminoguanidine bicarbonate.

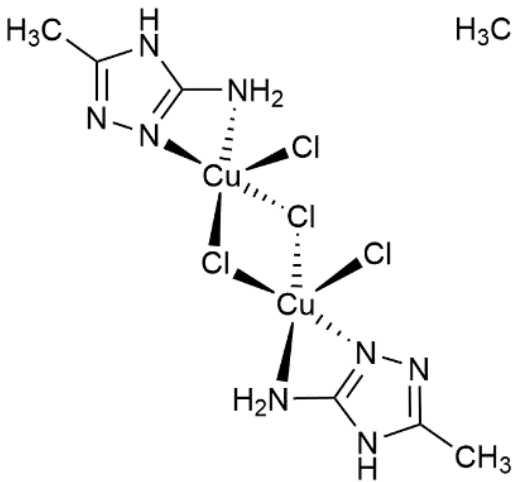

$10 a$

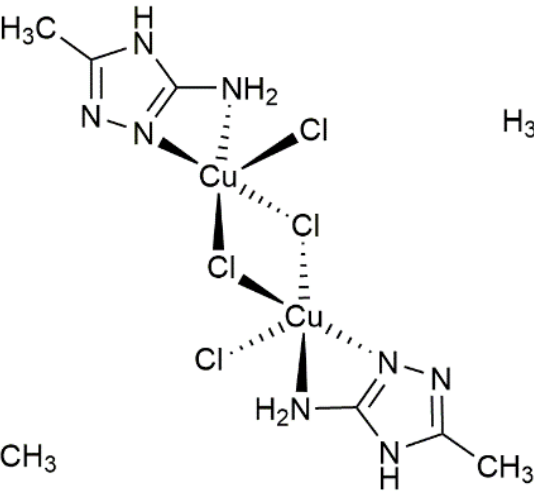

$10 b$<smiles></smiles>

11 
Figure 4 - Proposed structures of $\mathrm{Cu}$ (II) complexes showing chlorine atoms in trans (10b, 11) and cis (10a) configuration, as in bridging coordination (10a, 10b).

\subsection{NMR Spectroscopy Of The Zn Complexes}

The insoluble property of complex-7 delimited the use of techniques such as NMR spectroscopy to characterize this compound. The Hydrogen and Carbon-13 NMR for complex-8 showed chemical shifts that correlates with the influence on the magnetic environment due to the presence of the metal ion. The hydrogen chemical shifts related to the primary amine of the pta ligand were not significant nor the multiplet signal of the phenyl group upon coordination. Nevertheless, the doublet signal associated to the phenyl group has shifted from $\delta 7.93$ to 8.02, indicating that hydrogen atoms in orto position are in the same magnetic environment relative to the $\mathrm{Zn}$ (II) ion. These chemical shifts suggest that the pta ligand forms a chemical bond to the metal center through a specific conformation as shown by Figure $5(\mathbf{8 c})$. The proposed structure $\mathbf{8 c}$ differs from $8 \mathbf{a}$ and $\mathbf{8 b}$ concerning the configuration of the coordinated ligand to the metal as shown by Figure 3. On the other hand, these structural configurations have common metal-chlorine coordination modes, agreeing with the infrared spectroscopy.

The carbon-13 NMR of complex-8 revealed chemical shifts from the triazole ring of pta at $\delta$ $174.5,159.8$ to 173.7 , and 159.5 upon coordination. The chemical shifts for these carbon atoms also reinforces the bidentate coordination mode of the ligand, as previously indicated by the infrared spectroscopy.

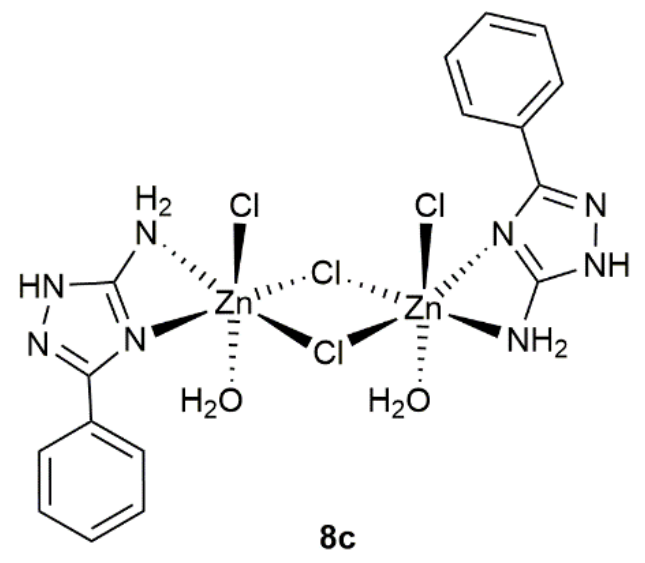

Figure 5 - Bidentate coordination mode of the pta ligand.

The hydrogen NMR of complex-9 showed chemical shifts associated to the amine group at $\delta$ $4.65,8.56$, and two broad ones at 6.74 and 7.24 , probably owing to hydrogen bonding or tautomeric equilibrium as shown by Figure 3 (Tavman, Boz, \& Birteksöz, 2010). The coordination of aminoguanidine to the $\mathrm{Zn}$ (II) ion in complex-9 is corroborated by the two carbon-13 chemical shifts at $\delta 155.8$ and 159.3, comparable to monodentate and bidentate coordination modes of palladium and platinum complexes with aminoguanidine in the range of $\delta 157.9$ to 165.5 , respectively (J. et al., 2007).

The decomposition of complex-8 into complex-9 in chloroform was also confirmed by the formation of $\mathrm{Zn}$ (II)-benzoate as byproduct (Egashira et al., 2003). Although the decomposition mechanism is unknown, the presence of coordinated water molecules in the sample of complex-8 let to speculate a possible intra-nucleophilic attack of the water on the pta ligand. As a consequence of this interaction, hydrogen chloride must be released, forming the compounds $\mathrm{Zn}$ (II)-benzoate and complex-9. Therefore, structural configurations of complex-9, beyond that shown by Figure 3, are also possible, including monodentate and bidentate coordination of the ligand by analogy with the palladium and platinum complexes (J. et al., 2007). In this regard, the equilibrium between the bidentate and monodentate coordination modes is conceivable for complex-9 as shown by Figure 6 , 
which corroborates with the two carbon-13 chemical shifts for this compound. A summary of the major NMR data of the compounds prepared in this work are shown in Table 2.

Table 2 - NMR $\left({ }^{1} \mathrm{H},{ }^{13} \mathrm{C}\right)$ data of the 1,2,4-triazole compounds and its metal derivatives.

\begin{tabular}{|c|c|c|c|c|c|c|}
\hline \multirow[t]{2}{*}{ Compound } & \multicolumn{3}{|c|}{${ }^{1} \mathrm{H}$} & \multicolumn{3}{|c|}{${ }^{13} \mathrm{C}$} \\
\hline & $\delta(\mathrm{NH})$ & $\delta\left(\mathrm{NH}_{2}\right)$ & $\delta(\mathrm{Ph})$ & $\delta\left(\mathbf{C}-\mathrm{NH}_{2}\right)$ & $\delta(\mathbf{C}-\mathrm{Ph})$ & $\delta(\mathrm{Ph})$ \\
\hline$p t a^{\dagger}$ & & $4.93 \mathrm{~s}$ & $\begin{array}{l}7.93 d \\
7.32-7.44 m\end{array}$ & 174.5 & 159.8 & $\begin{array}{l}137.6,130.2 \\
129.0,127.6\end{array}$ \\
\hline $8^{\dagger}$ & & 4.91s & $\begin{array}{l}8.02 \mathrm{~d} \\
7.36-7.47 \mathrm{~m}\end{array}$ & 173.7 & 159.5 & $\begin{array}{l}134.2,131.1 \\
129.4,127.5\end{array}$ \\
\hline $9^{*}$ & $8.56 \mathrm{~s}$ & $\begin{array}{l}4.65 \mathrm{~s}, \\
6.74 \mathrm{~b}, 7\end{array}$ & & $\begin{array}{l}159.3 \\
155.8\end{array}$ & & \\
\hline
\end{tabular}

Note: $\mathrm{s} \quad$ (singlet); $\mathrm{d}$ (doublet); $\mathrm{m}$ (multiplet); b(broad); $\quad{ }^{\dagger}-\mathrm{CD}_{3} \mathrm{OD} ; \quad \stackrel{*}{*}$.DMSO; $\quad\left[\mathrm{Zn}_{2}(\text { pta })_{2} \mathrm{Cl}_{4}\right] \cdot 3 \mathrm{H}_{2} \mathrm{O} \quad(\mathbf{8})$; $\left[\mathrm{Zn}_{2}(\text { amgu })_{2} \mathrm{Cl}_{2}\right] \cdot \mathrm{CHCl}_{3}(\mathbf{9})$;

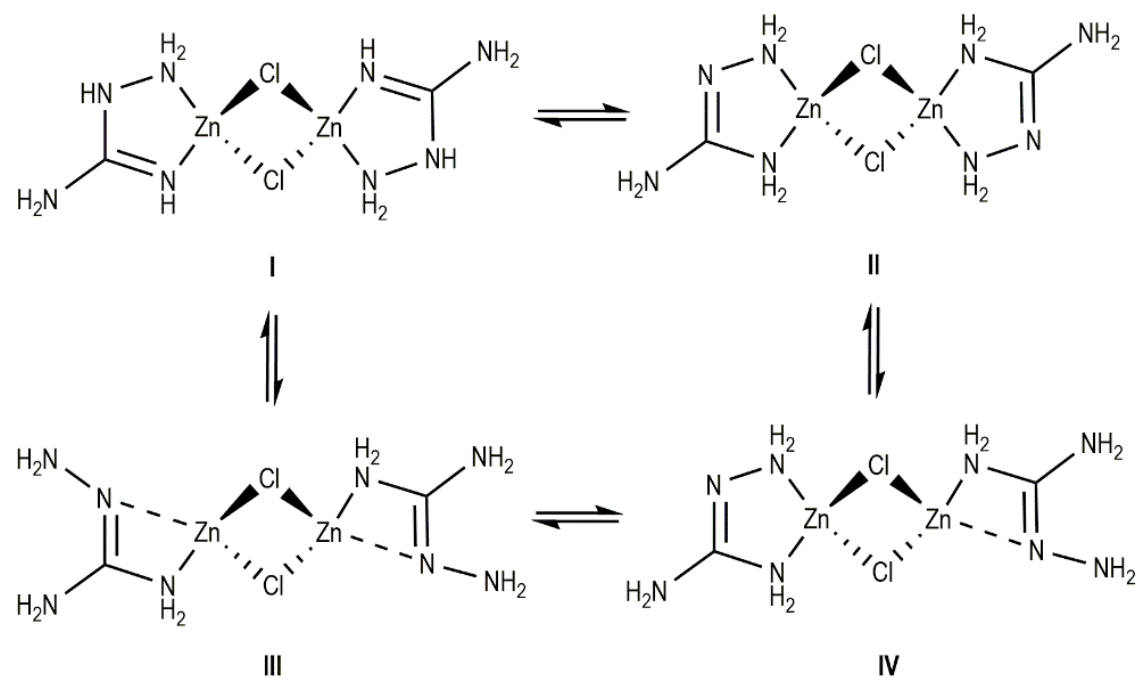

Figure 6 - Proposed chemical equilibrium of complex-9 in solution.

\subsection{The TGA and DSC Analysis}

The DSC curve of complex-7 showed two endothermic peaks at the temperatures of 545.2 and $592.4{ }^{\circ} \mathrm{C}$, and an exothermic around $562.2^{\circ} \mathrm{C}$. The absence of solubility and the thermal stability of this compound on elevated temperatures reveals the formation of an inorganic polymer (Archer, 2001). The correlation between the DSC and TGA data reinforces the formation of a polymeric material. The TGA shows loss of weight from $510^{\circ} \mathrm{C}$ and a residue around $710{ }^{\circ} \mathrm{C}$ due to oxidation and decomposition process of the sample. The DSC data of complex-7 suggests melting at $545.2{ }^{\circ} \mathrm{C}$, followed by a change in structural configuration or recrystallization at $562.2{ }^{\circ} \mathrm{C}$ and finally oxidation and decomposing around $592.4{ }^{\circ} \mathrm{C}$. Similar thermal process has been reported for the $1 \mathrm{D}$ polymeric compound of Cd(II)-3,4-diamino-1,2,4-triazole (Jin et al., 2015). The low frequency infrared data of complex-7 combined with its thermal analysis let to speculate that the triazole, in this polymeric material, might change its coordination mode as shown by Figure 7 . This changing in coordination mode is due to the increasing temperature in the DSC analysis before decomposition of the material. It is also conceivable that the metal ion is at the center of a tetrahedron and the chloride ions in the 
bridging coordination mode throughout the thermal analysis process. The proposed structural arrangements shown by Figure 7 ( $7 \mathbf{a}$ and $\mathbf{7 b}$ ) corroborate with the change in structural configuration observed by the exothermic peak for this compound. On the other hand, complex-7 probably has one of these structural configurations in the solid-state instead of a dimer as shown by Figure 2 . However, it is a difficult task to define which of these arrangements predominate in the solid state.
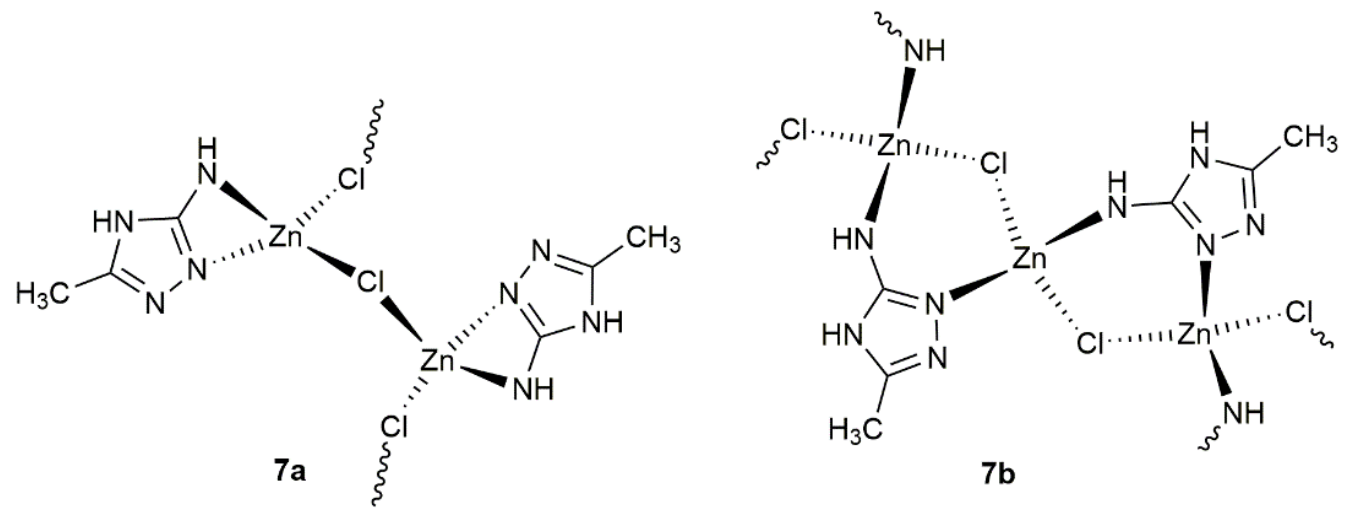

Figure 7 - Proposed polymeric structures for the complex-7.

\subsection{Electronic Spectroscopy - UV-VIS Of The Copper Complexes}

The spectra of complexes 10 and 11 revealed overlapped bands below $400 \mathrm{~nm}$ in methanol that falls in the visible region of the electronic spectrum, characteristic of the Metal-to-ligand Charge Transfer bands (MLCT). The $d$ - $d$ electronic transitions occurred at $719 \mathrm{~nm}$ for the complex-10, and $723 \mathrm{~nm}$ for the complex-11, typical of ligands from weak field. The proximity of these electronic bands may suggest that both correspond to the same structure in solution. Complex-10 has an extinction coefficient $(\varepsilon)$ of $76.7 \mathrm{~L} \mathrm{~mol}^{-1} \mathrm{~cm}^{-1}$ which is within the range of 71 to $478 \mathrm{~L} \mathrm{~mol}^{-1} \mathrm{~cm}^{-1}$ for compounds having a square planar or square pyramidal geometry (Godlewska, Jezierska, Baranowska, Augustin, \& Dołęga, 2013; Mishra, Tiwari, Mourya, Singh, \& Singh, 2015; Onawumi, Odunola, Suresh, \& Paul, 2011; Singh, Kaushik, Verma, Hundal, \& Gupta, 2009; Yusnita, Puvaneswary, Mohd. Ali, Robinson, \& Kwai-Lin, 2009). Although the value of $\varepsilon$ points to a square pyramidal geometry, the metal ion in complex-10 is probably at the center of a distorted trigonal bipyramidal geometry in solution. The extinction coefficient $(\varepsilon)$ of complex-11 was $7.0 \mathrm{~L} \mathrm{~mol}^{-1} \mathrm{~cm}^{-}$ ${ }^{1}$ which is associated to compounds of octahedral geometry with a center of symmetry (1 to $10 \mathrm{~L}$ $\mathrm{mol}^{-1} \mathrm{~cm}^{-1}$ ) as shown by Figure 4 (Hueeye, Keiter, \& Keiter, 1993). However, dimeric square pyramidal compounds of $\mathrm{Cu}(\mathrm{II})$, with chloride ions in terminal and bridging mode, showed $d-d$ transitions at $667 \mathrm{~nm}\left(\varepsilon=2.11 \mathrm{dm}^{3} \mathrm{~mol}^{-1} \mathrm{~cm}^{-1}\right)$ and $769 \mathrm{~nm}\left(\varepsilon=2.17 \mathrm{dm}^{3} \mathrm{~mol}^{-1} \mathrm{~cm}^{-1}\right)(\mathrm{Lu}, \mathrm{Wu}$, Zhang, \& Deng, 2017). By comparing the $\varepsilon$ values of these $\mathrm{Cu}(\mathrm{II})$-polypyridyl compounds with those of complex-11, the latter probably has either a distorted trigonal bipyramidal geometry in solution instead of an octahedron. In this perspective, one of the $\mathrm{NH}_{2}$ group of the mta may binds weakly to the metal ion, as previously suggested by the infrared spectroscopy, leading to a pseudo octahedral geometry in the solid state.

\subsection{Bacterial Activity}

The 1,2,4-triazoles compounds and the $\mathrm{Cu}$ (II) derivatives showed no activity at the highest experimental concentration for the microorganisms tested. The lack of solubility of complex-7 on DMSO restricted the biological investigation of this compound. The biological activity data for the compounds tested in this work are shown Table 3. 
Table 3 - Antimicrobial data* of the 1,2,4-triazole compounds and their metal derivatives.

\begin{tabular}{lcccc}
\hline Compound & $\begin{array}{c}\text { Staphylococcus } \\
\text { aureus }\end{array}$ & $\begin{array}{l}\text { Bacillus } \\
\text { subtilis }\end{array}$ & $\begin{array}{c}\text { Escherichia } \\
\text { coli }\end{array}$ & $\begin{array}{c}\text { Salmonella } \\
\text { typhimurium }\end{array}$ \\
\hline & & & & \\
$m t a$ & $n a$ & $n a$ & $n a$ & $n a$ \\
$p t a$ & $n a$ & $n a$ & $n a$ & $n a$ \\
$\mathbf{8}$ & $133.5(83.3)$ & $267.0(166.6)$ & $133.5(83.3)$ & $267.0(166.6)$ \\
$\mathbf{9}$ & $360.7(166.6)$ & $360.7(166.6)$ & $360.7(166.6)$ & $360.7(166.6)$ \\
$\mathbf{1 0}$ & $n a$ & $n a$ & $n a$ & $n a$ \\
$\mathbf{1 1}$ & $n a$ & $n a$ & $n a$ & $n a$ \\
Amoxicilin & $0.5(0.2)$ & $0.5(0.2)$ & $227(83.3)$ & $n a$ \\
Norfloxacin & $15.6(5.0)$ & $15.6(5.0)$ & $1.8(0.6)$ & $4.1(1.3)$ \\
$\mathrm{ZnCl}_{2} .2 \mathrm{H}_{2} \mathrm{O}$ & $1961.8(333.3)$ & $490.3(83.3)$ & $1961.8(333.3)$ & $1961.8(333.3)$ \\
$\mathrm{CuCl}_{2} .2 \mathrm{H}_{2} \mathrm{O}$ & $493.2(83.3)$ & $1973.4(333.3)$ & $n a$ & $n a$ \\
& & & & \\
\hline
\end{tabular}

Note: $\left[\mathrm{Zn}_{2}(p t a)_{2} \mathrm{Cl}_{4}\right] \cdot 3 \mathrm{H}_{2} \mathrm{O}(\mathbf{8}) ;\left[\mathrm{Zn}_{2}(a m g u)_{2} \mathrm{Cl}_{2}\right] \cdot \mathrm{CHCl}_{3}(\mathbf{9}) ;\left[\mathrm{Cu}_{2}(m t a)_{2} \mathrm{Cl}_{4}\right] \cdot \mathrm{H}_{2} \mathrm{O}(\mathbf{1 0}) ;\left[\mathrm{Cu}(m t a)_{2} \mathrm{Cl}_{2}\right] \cdot 2 \mathrm{H}_{2} \mathrm{O} \cdot \mathrm{CH}_{3} \mathrm{OH}$ (11).*Minimum Inhibitory Concentration (MIC) - $\mu \mathrm{M}(\mu \mathrm{g} / \mathrm{mL}) ; n a$-inactive compound at the highest concentration used in the experiment.

The correlation between structural features and the bioassay data is a difficult task. Several compounds of $\mathrm{Zn}$ (II) having tetrahedral geometry are reported presenting biological activity in a wide scale of MIC. The monomeric compound Zn(II)-2-bromo-4-chloro-6-[(2-morpholin-4ylethylimino)methyl]phenol, for instance, showed activity against $S$. aureus and $E$. coli with values of MIC between 2.0 and $8.0 \mu \mathrm{g} \mathrm{mL}^{-1}$. The ligand in this compound is acting in bidentate mode of coordination towards the metal íon (Hu, Zhao, Xue, \& Yang, 2016). The absence of lipophilicity has also been acknowledged as cause in decreasing the activity of the $\mathrm{Zn}$ (II)-salicylaldimine derivatives. These compounds showed MIC's in the range of 50 to $500 \mu \mathrm{g} \mathrm{mL}^{-1}$ against $S$ aureus (Kaczmarek, Jastrząb, Hołderna-Kędzia, \& Radecka-Paryzek, 2009). Other monomeric complexes of $\mathrm{Zn}$ (II) with Schiff bases showed biological activity presenting MIC's between 4.0 and $13.0 \mu \mathrm{g}$ $\mathrm{mL}^{-1}$ against $S$. aureus and E. coli (Xue, Li, Zhao, \& Yang, 2013; Xue, Zhao, Han, \& Feng, 2011). Compounds of Zinc having other ligands in bidentate coordination mode are reported as biologically active materials. This is the case of the octahedral complexes of $\mathrm{Zn}$ (II) with Schiff bases that showed MIC's of 150 and $125 \mu \mathrm{g} \mathrm{mL}^{-1}$ against $S$. aureus and E.coli respectively (Adly, Taha, \& Fahmy, 2013; Galini, Salehi, Kubicki, Amiri, \& Khaleghian, 2017; Taghizadeh, Montazerozohori, Masoudiasl, Joohari, \& White, 2017).

The data in Table 3 show that the only active metal complexes to the microorganisms tested were the $\mathrm{Zn}(\mathrm{II})$ derivatives. The MIC's are considerably superior to that of Amoxicilin and Norfloxacin. Complex-8 and $\mathbf{9}$ showed better bacterial results compared to the $\mathrm{Zn}$ (II) chloride, establishing a synergistic effect upon coordination. This effect on the bioassay of the $\mathrm{Zn}$ (II) compounds may be correlated to electronic properties, geometry, lability of the ligands and polarizability of the material in solution. For instance, this effect did not occur for the $\mathrm{Cu}$ (II) complexes which have a dimeric distorted trigonal bipyramidal geometry. The resulting bioactivity of the complex-8 when associated with its octahedral geometry suggest that the latter prevails over the tetrahedral geometry of complex-9. The presence of weak ligands such as chloride ion and water molecules bonded to the Z(II) ion provide them with the property of being labile in complex-8, leading to an increase in polarizability of the complex in solution, this effect do not occur in complex-9. Although the mechanism of action is unknown, the activity of complex-8 suggests an effective crossing through the cell wall of the microorganisms probably due to the polarizability effect in solution. In this context, it is reasonable to assume that the inactivity of the copper(II) compounds, $\mathbf{1 0}$ and 11, is correlated to absence of effective polarizability of these compounds in solution. 


\section{Conclusion}

The copper compounds showed no activity against the microorganisms tested; however, novel compounds have been synthesized, and characterized. Despite the 1,2,4-triazole molecules be inactive against the microorganisms tested, their zinc complexes revealed activity upon coordination and synergistic effect. The commercial drugs, Amoxicillin and Norfloxacin, showed higher activity in comparison to the $\mathrm{Zn}(\mathrm{II})$ complexes, 8 and $\mathbf{9}$. Nevertheless, these complexes can eventually be useful in future as medicinal drugs for renewed formulations in the treatment of illnesses correlated to the microorganisms tested in this work.

\section{Acknowledgements}

The authors are grateful to the Brazilian Agencies CAPES, CNPq and FAPEMIG for the financial support by granting a scholarship to the postgraduate student in this project.

\section{References}

Adly, O. M. I., Taha, A., \& Fahmy, S. A. (2013). Synthesis, spectral characterization, molecular modeling and antimicrobial activity of new potentially N2O2 Schiff base complexes. Journal of Molecular Structure, 1054-1055(Supplement C), 239-250. doi:https://doi.org/10.1016/j.molstruc.2013.09.037

Archer, R. D. (2001). Inorganic and Organometallic Polymers. New York: John Wiley \& Sons. Inc., Publication.

Arjmand, F., Sayeed, F., \& Muddassir, M. (2011). Synthesis of new chiral heterocyclic Schiff base modulated $\mathrm{Cu}(\mathrm{II}) / \mathrm{Zn}$ (II) complexes: Their comparative binding studies with CT-DNA, mononucleotides and cleavage activity. Journal of Photochemistry and Photobiology B: Biology, 103(2), 166-179. doi:http://dx.doi.org/10.1016/j.jphotobiol.2011.03.001

Berlini, L., de Souza, M. C., De Abreu, H. A., Leitao, A. A., Maia, J. R. D., \& Diniz, R. (2009). Intermolecular interactions on the crystal packing of 1,6-bis(pyrimidin-2-ylthio)hexane: Spectroscopic and theoretical investigation. Journal of Molecular Structure, 935(1-3), 123128. doi:10.1016/j.molstruc.2009.07.002

Bianucci, A. M., Demartin, F., Manassero, M., Masciocchi, N., Ganadu, M. L., Naldini, L., \& Panzanelli, A. (1991). Metal complexes of cimetidine. Synthesis, X-ray structure determination and semiempirical calculations on the [cimetidinatecopper(II)]+ cation. Inorganica Chimica Acta, 182(2), 197-204. doi:https://doi.org/10.1016/S00201693(00)90155-5

Boechat, N., Pinheiro, L. C. S., Santos-Filho, O. A., \& Silva, I. C. (2011). Design and Synthesis of New N-(5-Trifluoromethyl)-1H-1,2,4-triazol-3-yl Benzenesulfonamides as Possible Antimalarial Prototypes. Molecules, 16(9), 8083.

Deng, X.-Q., Song, M.-X., Zheng, Y., \& Quan, Z.-S. (2014). Design, synthesis and evaluation of the antidepressant and anticonvulsant activities of triazole-containing quinolinones. European $\begin{array}{llll}\text { Journal of Medicinal Chemistry, 217-224. } & \text { 73, }\end{array}$ doi:http://dx.doi.org/10.1016/j.ejmech.2013.12.014

Devi, R. K. B., Devi, S. P., Singh, R. K. B., Singh, R. K. H., Swu, T., Devi, W. R., \& Singh, C. H. B. (2014). Synthesis, spectroscopic, and biological studies on copper(II) complexes containing equatorial-apical chloride bridges: crystal structure of $[\mathrm{Cu} 2$ (?-Cl) 2 (O-2butoxyethylpyridine-2-carboximidate) $2 \mathrm{Cl} 2$ ]. Journal of Coordination Chemistry, 67(5), 891-909. doi:10.1080/00958972.2014.902449

Egashira, T., Sakai, K., Takayama, F., Sakurai, M., \& Yoshida, S. (2003). Zinc benzoate, a contaminating environmental compound derived from polystyrene resin inhibits A-type monoamine oxidase. Toxicology Letters, 145(2), 161-165. doi:https://doi.org/10.1016/S03784274(03)00286-8 
Galani, A., Efthimiadou, E. K., Mitrikas, G., Sanakis, Y., Psycharis, V., Raptopoulou, C., .. . Karaliota, A. (2014). Synthesis, crystal structure and characterization of three novel copper complexes of Levofloxacin. Study of their DNA binding properties and biological activities. Inorganica Chimica Acta, 423, 207-218. doi:https://doi.org/10.1016/j.ica.2014.08.005

Galini, M., Salehi, M., Kubicki, M., Amiri, A., \& Khaleghian, A. (2017). Structural characterization and electrochemical studies of $\mathrm{Co}(\mathrm{II}), \mathrm{Zn}(\mathrm{II}), \mathrm{Ni}(\mathrm{II})$ and $\mathrm{Cu}$ (II) Schiff base complexes derived from 2-((E)-(2-methoxyphenylimino)methyl)-4-bromophenol; Evaluation of antioxidant and antibacterial properties. Inorganica Chimica Acta, 461, 167-173. doi:https://doi.org/10.1016/j.ica.2017.02.001

Godlewska, S., Jezierska, J., Baranowska, K., Augustin, E., \& Dołęga, A. (2013). Copper(II) complexes with substituted imidazole and chlorido ligands: X-ray, UV-Vis, magnetic and EPR studies and chemotherapeutic potential. Polyhedron, 65, 288-297. doi:http://dx.doi.org/10.1016/j.poly.2013.08.039

Graci, J. D., \& Cameron, C. E. (2006). Mechanisms of action of ribavirin against distinct viruses. Reviews in Medical Virology, 16(1), 37-48. doi:10.1002/rmv.483

Hu, X. M., Zhao, G. Q., Xue, L. W., \& Yang, W. C. (2016). Synthesis, crystal structures, and antimicrobial activity of copper(II) and zinc(II) complexes derived from 2-bromo-4-chloro-6[(2-morpholin-4-ylethylimino)methyl]phenol. Russian Journal of Coordination Chemistry, 42(6), 418-422. doi:10.1134/s107032841605002x

Hueeye, J. E., Keiter, E. A., \& Keiter, R. L. (1993). Inorganic Chemistry Principles of Structure and Reactivity (4 ed.). New York: HarperCollins College Publishers.

Indoria, S., Lobana, T. S., Singh, D., Kumari, S., Kumari, P., Bala, T., . . . Jasinski, J. P. (2015). Stabilization of CuII-I Bonds Using 2-Benzoylpyridine Thiosemicarbazones - Synthesis, Structure, Spectroscopy, Fluo-rescence, and Cyclic Voltammetry. European Journal of Inorganic Chemistry, 2015(30), 5106-5117. doi:doi:10.1002/ejic.201500618

J., A. D., Alberto, A., Arnaud, G., Henri-Philippe, H., Georges, M., Dung, N. H., . . Bernard, V. (2007). Platinum(II) and Palladium(II) Complexes with N-Aminoguanidine. European Journal of Inorganic Chemistry, 2007(21), 3327-3334. doi:doi:10.1002/ejic.200600998

Jin, X., Xu, C.-X., Yin, X., He, P., \& Zhang, J.-G. (2015). A 1D cadmium complex with 3,4diamino-1,2,4-triazole as ligand: synthesis, molecular structure, characterization, and theoretical studies. Journal of Coordination Chemistry, 68(11), 1913-1925. doi:10.1080/00958972.2015.1029465

Johnson, E. M., Szekely, A., \& Warnock, D. W. (1999). In Vitro Activity of Syn-2869, a Novel Triazole Agent, against Emerging and Less Common Mold Pathogens. Antimicrobial Agents and Chemotherapy, 43(5), 1260-1263.

Kaczmarek, M. T., Jastrząb, R., Hołderna-Kędzia, E., \& Radecka-Paryzek, W. (2009). Selfassembled synthesis, characterization and antimicrobial activity of zinc(II) salicylaldimine complexes. Inorganica Chimica Acta, 362(9), 3127-3133. doi:https://doi.org/10.1016/j.ica.2009.02.012

Lu, X., Wu, N., Zhang, B., \& Deng, K. (2017). Copper(II) complexes of two TEMPO-functionalized polypyridyl ligands: structure and catalytic activity in alcohol oxidation. Journal of Coordination Chemistry, 70(3), 475-486. doi:10.1080/00958972.2016.1272675

Ma, T., Xu, J., Wang, Y., Yu, H., Yang, Y., Liu, Y., . . . Zhu, T. (2015). Ternary copper(II) complexes with amino acid chains and heterocyclic bases: DNA binding, cytotoxic and cell apoptosis induction properties. Journal of Inorganic Biochemistry, 144, 38-46. doi:https://doi.org/10.1016/j.jinorgbio.2014.12.011

Mishra, M., Tiwari, K., Mourya, P., Singh, M. M., \& Singh, V. P. (2015). Synthesis, characterization and corrosion inhibition property of nickel(II) and copper(II) complexes with some

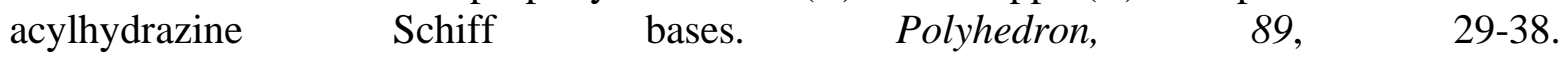
doi:http://dx.doi.org/10.1016/j.poly.2015.01.003

Mohamed, E. L. A., Ahmami, E. L. M., \& Ali, A. (2016). SYNTHESIS AND CHARACTERIZATION OF ZN(II) AND CD(II) SALEN COMPLEXES, SALEN L1H2, 


\section{L2H2 N,N'-BIS (SALICYLIDENE)-8,11 DIAMINOCTANE AND N,N'-BIS} (SALICYLIDENE)-8,13 DIAMINODECANE. International Journal of Pharmaceutical, Chemical \& Biological Sciences, 6(2), 108-116.

Naito, Y., Akahoshi, F., Takeda, S., Okada, T., Kajii, M., Nishimura, H., . . Kagitani, Y. (1996). Synthesis and Pharmacological Activity of Triazole Derivatives Inhibiting Eosinophilia. Journal of Medicinal Chemistry, 39(15), 3019-3029. doi:10.1021/jm9507993

Nakamoto, K. (1997). Infrared and Raman Spectra of Inorganic and Coordination Compounds Part B: Applications in Coordination, Organometallic, and Bioinorganic Chemistry (5th ed.). New York: John Wiley \& Sons Inc.

NCCLS. (2002). Reference Method for Broth Dilution Antifungal Susceptibility Testing of Yeasts. In NCCLS document M27-A2 (Approved Standard - Second Edition ed., Vol. 22). Pennsylvania, USA: Wayne.

NCCLS. (2003). Method for Dilution Antimicrobial Susceptibility Tests for Bacteria that Grow Aerobically. In NCCLS document M7-A6. Pennsylvania, USA.

Onawumi, O. O. E., Odunola, O. A., Suresh, E., \& Paul, P. (2011). Synthesis, structural characterization and microbial activities of mixed ligand copper(II) complexes of 2,2'bipyridine and acetylacetonate. Inorganic Chemistry Communications, 14(10), 1626-1631. doi:http://dx.doi.org/10.1016/j.inoche.2011.06.025

Roberts, J., Schock, K., Marino, S., \& Andriole, V. T. (2000). Efficacies of Two New Antifungal Agents, the Triazole Ravuconazole and the Echinocandin LY-303366, in an Experimental Model of Invasive Aspergillosis. Antimicrobial Agents and Chemotherapy, 44(12), 33813388. doi:10.1128/aac.44.12.3381-3388.2000

Silverstain, R. M., Bassler, G. C., \& Morril, T. C. (1991). Spectrometric Identification of Organic Compounds (Fifth ed.). New York: John Wiley \& Sons, INC.

Singh, A. P., Kaushik, N. K., Verma, A. K., Hundal, G., \& Gupta, R. (2009). Synthesis, structure and biological activity of copper(II) complexes of 4-(2-pyridylmethyl)-1,7-dimethyl-1,4,7triazonane-2,6-dione and 4-(2-pyridylethyl)-1,7-dimethyl-1,4,7-triazonane-2,6-dione. European Journal of Medicinal Chemistry, 44(4), 1607-1614. doi:http://dx.doi.org/10.1016/j.ejmech.2008.07.029

Taghizadeh, L., Montazerozohori, M., Masoudiasl, A., Joohari, S., \& White, J. M. (2017). New tetrahedral zinc halide Schiff base complexes: Synthesis, crystal structure, theoretical, 3D Hirshfeld surface analyses, antimicrobial and thermal studies. Materials Science and Engineering: C, 77, 229-244. doi:https://doi.org/10.1016/j.msec.2017.03.150

Tavman, A., Boz, I., \& Birteksöz, A. S. (2010). Spectral characterization and antimicrobial activity of 2-(5-chloro/nitro-1H-benzimidazol-2-yl)-4-bromo/nitro-phenols and their zinc(II) complexes. Spectrochimica Acta Part A: Molecular and Biomolecular Spectroscopy, 77(1), 199-206. doi:https://doi.org/10.1016/j.saa.2010.05.008

Xue, L. W., Li, X. W., Zhao, G. Q., \& Yang, W. C. (2013). Synthesis, structures, and antimicrobial activity of nickel(II) and zinc(II) complexes with Schiff bases derived from 3bromosalicylaldehyde. Russian Journal of Coordination Chemistry, 39(12), 872-876. doi:10.1134/s1070328413110092

Xue, L. W., Zhao, G. Q., Han, Y. J., \& Feng, Y. X. (2011). Synthesis, structures, and antimicrobial activity of nickel(II) and Zinc(II) complexes with 5-methoxy-2-[(3methylaminopropylimino)methyl]phenol. Russian Journal of Coordination Chemistry, 37(4), 262. doi: $10.1134 / \mathrm{s} 1070328411030110$

Yusnita, J., Puvaneswary, S., Mohd. Ali, H., Robinson, W. T., \& Kwai-Lin, T. (2009). Synthesis, structural characterization and antibacterial activity of 2,6-diacetylpyridine bis(benzenesulfonohydrazide) Schiff bases and their copper(II) complexes. Polyhedron, 28(14), 3050-3054. doi:http://dx.doi.org/10.1016/j.poly.2009.06.059

Zacchino, S. A., \& Gupta, M. P. (2007). Manual de técnicas in vitro para la deteccíon de compuestos antifúngicos: Corpus Libros Médicos y Científicos. 